\title{
Peran Media Dalam Pemberantasan Korupsi
}

\author{
Oleh \\ Sanur Purnomo
}

\begin{abstract}
Abstrak
Peran media dalam pemberantasan korupsi ini sudah diulas oleh berbagai penulis hebat diberbagai karya ilmiah, namun penulis perlu mereview kembali untuk dishare ke publik tentu saja digunakan untuk mencegah dan memberantas korupsi mengingat kasus-kasus korupsi sering marak terjadi. Tulisan ini memaparkan isi pikiran dari berbagai ahli hukum terkait korupsi. Pendekatan dalam penulisan ini ini lebih ditekankan pada masalah "peran media dalam pemberantasan korupsi" dengan tujuan untuk memperoleh input tentang problemaproblema yang di hadapi pada pelaksanaanya di lapangan. Mengingat kejahatan ini termasuk kategori luar biasa, sehingga wajib ditangani juga dengan luar biasa. Pada hakikatnya korupsi adalah The abuse of public position for personal gain or of the benefit of an individual or group tho whom one owes allegiance. Korupsi sesungguhnya bukanlah milik eksklusif negara-negara berkembang. Jadi korupsi adalah sebuah fenomena global, meskipun tingkat keparahan dari negara yang satu ke negara yang lain bisa berbeda-beda. Strategi pemberantasan korupsi yaitu partisipasi publik yang berkaitan dengan pengawasan dan supervisi (termasuk oleh masyarakat). Pasrtisipasi publik di dalam pemberantasan korupsi bisa dilakukan dalam kerangka pencegahan maupun penegakkan hukum terhadap kasuskasus korupsi. Secara umum diakui bahwa keikutsertaan masyarakat termasuk media akan berpeluang menurunkan tingkat korupsi. Bahkan da sebuah kota di Italai namanya Bologna, daerah tersebut dikenal dengan sebutan "kota kasus korupsi". Menurutnya korupsi itu merupakan gejala sosial atau pola perilaku manusia dalam masyarakat. Upaya pemberantasan korupsi itu yang lebih penting ialah partisipasi publik dan pengaturan mengenai faktor publik. Peran media itu juga sangat besar terhadap upaya pemberantasan korupsi. Media itu bisanya selalu berkeinginan untuk menyampaikan berita-berita yang sangat menarik supaya diminati orang. Sehingga untuk mewujudkan nya diperlukan profesionalisme.
\end{abstract}

Kata Kunci: Media; Pemberantasan; Korupsi;

\section{Latar Belakang}

Peran media dalam pemberantasan korupsi ini sudah diulas oleh berbagai penulis hebat diberbagai karya ilmiah, namun penulis perlu mereview kembali untuk dishare ke publik tentu saja digunakan untuk mencegah dan memberantas korupsi mengingat kasuskasus korupsi sering marak terjadi.

Tulisan ini memaparkan isi pikiran dari berbagai ahli hukum terkait korupsi. Pendekatan dalam penulisan ini ini lebih ditekankan pada masalah "peran media dalam pemberantasan korupsi" dengan tujuan untuk memperoleh input tentang problemaproblema yang di hadapi pada pelaksanaanya di lapangan. Mengingat kejahatan ini termasuk kategori luar biasa, sehingga wajib ditangani juga dengan luar biasa.

\section{Rumusan Masalah}

Seperti apa peranan media dalam upaya pemberantasan korupsi di Republik Indonesia? 


\section{Pembahasan}

Korupsi ini tidak hanya merugikan keuangan negara, akan tetapi juga kerugian terhadap perekonomian masyarakat secara luas. Adapun gagasan beberapa ahli hukum terkait dengan peran media dalam upaya pemberantasan korupsi tersebut yaitu:

a. Sasongko Tedjo

Menurut Sasongko Tedjo, upaya pemberantasan korupsi secara konkret di indonesia saat ini dalam taraf menguat, setelah kehadiran institusi dengan peran protagonis, yakni Komisi Pemberantasan Korupsi (KPK).

Selain itu peran media juga sangat kuat dalam upaya pemberantasan korupsi, maka menarik untuk membandingkan dua kondisi Eksterm, yakni pada era kekuasaan orde baru dan era liberalisasi media pasca orde baru.

Pada era pemerintahan orde baru, pers berada dalam posisi menerima baik sukarela maupun terpakasa. Pers merupakan penyelamat bangsa dari bahaya komunisme, membuat pangan berlimpah dan murah, pencipta pasar melalui mekanisme APBN, serta memiliki misi untuk melaksanakan pembangunan demi kesejahteraan bangsa. Pada era liberalisasi pasca orde baru, pers lebih bisa menjalankan fungsinya secara lebih leluasa yakni:

1) Fungsi kontrol atas kekuasaan (watchdog)

2) Fungsi fasilisator debat/dialog publik.

b. Abdullah Hehamahua

Menurut Abdullah Hehamahua, korupsi itu dapat dibagi atas tiga pengertian yaitu:

1) Material Corruption yaitu penyelewengan yang bersifat materi uang

2) Political Corruption yaitu penyelewengan dalam bentuk manipulasi dalam pemilu, komersialisasi jabatan, keputusan, dsb.

3) Intellectual corruption yaitu penyelewengan yang muncul dalam bentuk manipulasi informasi atau ilmu pengetahuan (pers sering melakukan korupsi jenis ini).

4) Korupsi juga didasarkan atas motif perbuatan yaitu

a) Corruption by need (PNS, Pegawai Swasta, dll)

b) Corruption by greed (orang yang mempunyai jabatan, dll)

c) Corruption by opportunities (Dosen, dll)

d) Corruption by Exposures (korupsi berjamaah, Presiden-RT, majikan supir, dll).

Selain motif perbuatan, korupsi juga dapat digolongkan atas 7 jenis yaitu:

1) Korupsi yang terkait dengan kerugian keuangan negara

2) Korupsi yang terkait dengan suap menyuap baik pasif maupun aktif

3) Korupsi yang terkait dengan penggelapan dalam jabatan 
4) Korupsi yang terkait dengan pemerasan (urus KTP, Catatan Sipil)

5) Korupsi yang terkait dengan perbuatan curang

6) Korupsi yang terkait dengan benturan dalam kepentingan pengadaan

7) Korupsi yang terkait dengan gratifikasi.

c. Amendo

Menurut Amendo, korupsi yang terjadi pada berbagai strata kehidupan masyarakat serta dilakukan dengan berbagai cara secara perlahan namun pasti mulai dianggap sebagai hal yang biasa. Upaya-upaya pemberantasan korupsi biasanya terasosiasikan secara lekat dengan pembuatan instrumen hukum anti korupsi yang baik dan pembentukan kelengkapan institusional untuk mengatasi korupsi serta yang lebih penting lagi ialah partisipasi publik.

Pada hakikatnya korupsi adalah "The abuse of public position for personal gain or of the benefit of an individual or group tho whom one owes allegiance" korupsi sesungguhnya bukanlah milik eksklusif negara-negara berkembang. Jadi korupsi adalah sebuah fenomena global, meskipun tingkat keparahan dari negara yang satu ke negara yang lain bisa berbeda-beda.

Strategi pemberantasan korupsi yaitu partisipasi publik yang berkaitan dengan pengawasan dan supervisi (termasuk oleh masyarakat). Pasrtisipasi publik di dalam pemberantasan korupsi bisa dilakukan dalam kerangka pencegahan maupun penegakkan hukum terhadap kasus-kasus korupsi. Dalam kerangka pencegahan, secara umum diakui bahwa keikutsertaan masyarakat termasuk media akan berpeluang menurunkan tingkat korupsi.

d. Prof. Dr. Blankenburg

Menurut Prof. Dr. Blankenburg, kasus-kasus mengenai korupsi tidak hanya dilakukan di indonesia saja melainkan juaga terdapat digara-negara yang lain.

Bahkan ada sebuah kota di Italai namanya Bologna, daerah tersebut dikenal dengan sebutan "kota kasus korupsi". Menurutnya korupsi itu merupakan gejala sosial atau pola perilaku manusia dalam masyarakat.

\section{Kesimpulan}

Upaya pemberantasan korupsi itu yang lebih penting ialah partisipasi publik dan pengaturan mengenai faktor publik. Peran media itu juga sangat besar terhadap upaya pemberantasan korupsi. Media itu bisanya selalu berkeinginan untuk menyampaikan berita-berita yang sangat menarik supaya diminati orang. Sehingga untuk mewujudkan nya diperlukan profesionalisme yang mendukung hasil kerja dalam pemberitaan nya. Akan tetapi seringkali media itu memberitakan hal-hal yang sangat jelek sehingga mempengaruhi 
tatanan kehidupan masyarakat sehingga untuk mengatasi kondisi seperti ini maka diperlukan kontrol sosial dari masyrakat.

\section{DAFTAR PUSTAKA}

Rhona K. M. Smith, et. al. 2008. Hukum Hak Asasi Manusia. PUSHAM-UII, Yogyakarta.

Roestandi, Achmad. 2005. Mahkamah Konstitusi dalam Tanya Jawab. Setjen dan Kepaniteraan MK, Jakarta.

Telaumbanua, Dalinama. 2014. "Pengembangan dan Promosi Pariwisata Kepulauan Nias." Center for Open Science.

Telaumbanua, Dalinama. 2015. "PERTANGGUNGJAWABAN PIDANA KORPORASI DI BIDANG LINGKUNGAN HIDUP." Refleksi Hukum: Jurnal Ilmu Hukum. vol. 9, no. 1

Danil, Elwi. 2012. Korupsi: Konsep, Tindak Pidana, dan Pemberantasannya. Rajawali Pers, Jakarta.

Djaja, Ermansyah. 2013. Memberantas Korupsi Bersama KPK. Sinar Grafika, Jakarta.

Effendi, Masyhur. 1994. Dimensi dan Dinamika Hak Asasi Manusia dalam Hukum Nasional dan Internasional. Ghalia Indonesia, Jakarta.

Telaumbanua, Dalinama. 2015. “Aspek Hukum Commercial Paper." Center for Open Science. No. 84pjc

http:/ / www.lombalomba.com/?s=penegak an+hukum+orde+lama

https://osf.io/xtdba/download?format=pd $\mathrm{f}$

http://id.wikipedia.org/wiki/Orde_Baru

Imam dan A.Ahsin Thohari, Dasar-Dasar Politik Hukum, RajaGrafindo Persada , Jakarta, 2005.

Telaumbanua, Dalinama. 2017. "ANALISIS PUTUSAN JUDEX FACTI TENTANG HAK CIPTA (Studi Putusan Nomor 05/HKI. Hak Cipta/2016/PN Niaga. Sby)." Jurnal Education and Development. vol. 6, no. 5

Hamzah, Andi. 2008. Hukum Acara Pidana Indonesia. Sinar Grafika Offset, Jakarta.
Telaumbanua, Dalinama. 2018. "Pembentukan Peraturan Daerah Kabupaten/Kota." Jurnal Education and Development. vol. 4, no. 1

http://ditjenpp.kemenkumham.go.id/htndan-puu/480-politik-perundangundangan.html

Telaumbanua, Dalinama. 2019. "Analisis Peraturan Perundang-undangan Koperasi Dengan Tujuan Hukum.”

Atmasasmita, Romli. 2004. Sekitar Masalah Korupsi Aspek Nasional dan Aspek Internasional. Mandar Maju, Bandung.

Telaumbanua, Dalinama. 2019. "Kumpulan Undang-undang KPK Dalam Satu Naskah." LawArXiv. November 29. doi:10.31228/osf.io/ysju2.

Undang-Undang Republik Indonesia Nomor 31 Tahun 1999 tentang Pemberantasan Tindak Pidana Korupsi.

Undang-Undang Republik Indonesia Nomor 39 Tahun 1999 tentang Hak Asasi Manusia

Undang-Undang Republik Indonesia Nomor 20 Tahun 2001 tentang Perubahan Atas Undang-Undang Nomor 31 Tahun 1999 tentang Pemberantasan Tindak Pidana Korupsi.

Undang-Undang Republik Indonesia Nomor 19 Tahun 2019 tentang Perubahan Kedua Atas UndangUndang Nomor 30 Tahun 2002 tentang Komisi Pemberantasan Tindak Pidana Korupsi

Telaumbanua, Dalinama. 2019. "Kumpulan Undang-undang KPK Dalam Satu Naskah." LawArXiv. November 29. doi:10.31228/osf.io/ysju2.

Zainuri, Achmad. 2007. Akal Kultural Korupsi di Indonesia. Cahaya Baru Sawangan, Depok.

Telaumbanua, Dalinama. 2020. "Restriktif Status Dewan Pengawas KPK." 
Jurnal Education and Development. vol. 8 , no. 1

Mulya Lubis, Todung. 1993. In search of Human Rights Legal-Political Dilemmas of Indonesia,s New Order, 1966-1990. Gramedia, Jakarta.

Samudera, Teguh. 1992. Hukum Pembuktian Dalam Acara Perdata. Alumni, Bandung.

Soekanto, Soerjono. Pengantar Penelitian Hukum. Sinar Grafika, Jakarta. 